\title{
DECISION SUPPORT SYSTEM FOR DETERMINING SCHOLARSHIP RECIPIENTS USING TOPSIS FMADM METHOD
}

\author{
Ismail Husein ${ }^{1}$, Dedy Juliandri Panjaitan ${ }^{2}$ \\ 1Department of Mathematics \\ UINSU Medan \\ 2Department of Mathematic Education \\ UMN Al-Washliyah \\ husein_ismail@uinsu.ac.id
}

\begin{abstract}
Granting scholarships to students aims to assist students in conducting lectures. Distribution of scholarships conducted by Muslim University Nusantara AlWashliyah to help underprivileged or underachievers during their study The problem aims to choose some best alternative based on some attributes (criteria) used. In order to make decisions on fuzzy issues can be used Fuzzy Multiple AttributeDecision Making (FMADM). In this research modeling using Unified Modeling Language (UML) in FMADM with TOPSIS method and Weighted Product to select candidates of scholarship recipients.
\end{abstract}

Key Word: Fuzzy Multiple Attribute Decision Making, Topsis, Weighted Product, Scholarship

\begin{abstract}
Abstrak. Pemberian beasiswa kepada mahasiswa bertujuan untuk membantu mahasiswa didalam melaksanakan perkuliahan. Pembagian beasiswa dilakukan oleh Universitas Muslim Nusantara Al-Washliyah untuk membantu mahasiswa yang kurang mampu ataupun berprestasi selama menempuh studinya Permasalahan tersebut bertujuan untuk memilih beberapa alternatif terbaik berdasarkan beberapa atribut (kriteria) yang digunakan. Dalam rangka pengambilan keputusan pada permasalahan yang bersifat fuzzy dapat digunakan Fuzzy Multiple AttributeDecision Making (FMADM). Pada penelitian ini dilakukan pemodelan menggunakan Unified Modelling Language (UML) pada FMADM dengan metode TOPSIS dan Weighted Product untuk menyeleksi calonpenerima beasiswa.
\end{abstract}

Kata Kunci: Fuzzy Multiple Attribute Decision Making, Topsis, Weighted Product, Scholarship 


\section{PENDAHULUAN}

Universitas Muslim Nusantara Al-Washliyah memiliki beasiswa yang ditawarkan kepada mahasiswa yang berprestasi dan yang kurang mampu. Untuk mendapatkan beasiswa tersebut maka harus sesuai dengan aturan-aturan yang telah ditetapkan. Kriteria yang ditetapkan dalam studi kasus ini adalah nilai indeks prestasi akademik, penghasilan orang tua, jumlah saudara kandung, jumlah tanggungan orang tua, semester,usia dan lain-lain. Oleh sebab itu tidak semua yang mendaftarkan diri sebagai calon penerima beasiswa tersebut akan diterima, hanya yang memenuhi kriteria-kriteria saja yang akan memperoleh beasiswa tersebut. Oleh karena jumlah peserta yang mengajukan beasiswa banyak serta indikator kriteria yang banyak juga, maka perlu dibangun sebuah sistem pendukung keputusan yang akan membantu penentuan siapa yang berhak untuk mendapatkan beasiswa tersebut.

Model yang digunakan dalam sistem pendukung keputusan ini adalah Fuzzy Multiple Attribute Decision Making (FMADM). Metode SAW ini dipilih karena metode ini menentukan nilai bobot untuk setiap atribut, kemudian dilanjutkan dengan proses perankingan yang akan menyeleksi alternative terbaik dari sejumlah alternatif, dalam hal ini alternatif yang dimaksud adalah yang berhak menerima beasiswa berdasarkan kriteria-kriteria yang ditentukan Top of Form

Dalam perkembangannya, penelitian tentang MADM juga fokus pada bagaimana para pembuat keputusan memberikan mereka preferensi pada alternatif tertentu dan kriteria. Biasanya, para pembuat keputusan memberi preferensi pembobotan numerikuntuk membuat perhitungan lebih mudah. Namun, preferensi linguistik saat ini juga diterapkan untuk menyederhanakan pengambil keputusan dalam memberikan pendapat mereka. Sebagai contoh, nilai alternatif A1 adalah "sangat baik" dalam criteria C1, sedangkan alternatif A1 adalah "moderat" dalam criteria C2. Tingkat kepentingan dari C1 adalah "sangat tinggi", sedangkan criteria C2 adalah "rendah" tingkat kepentingan, dan sebagainya. Jika preferensi diberikan secara lingustik, maka fuzzy logic dapat digunakan untuk membantu memecahkan masalah. Fuzzy logic sangat efektif untuk memecahkan masalah MADM dimana data yang diberikan adalah ambigu atau dipresentasikan secara linguistik. Pada kenyataannya, ada banyak keputusan dibuat di dalam lingkungan fuzzy. 
Dengan metode perangkingan tersebut, diharapkan penilaian akan lebih tepat karena didasarkan pada nilai kriteria dan bobot yang sudah ditentukan sehingga akan mendapatkan hasil yang lebih akurat terhadap siapa yang akan menerima beasiswa tersebut.

\section{DASAR TEORI}

\section{Sistem Pendukung Keputusan}

SPK sebagai sebuah sistem berbasis komputer yang membantu dalam proses pengambilan keputusan. SPK sebagai sistem informasi berbasis komputer yang adaptif, interaktif, fleksibel, yang secara khusus dikembangkan untuk mendukung solusi dari pemasalahan manajemen yang tidak terstruktur untuk meningkatkan kualitas pengambilan keputusan. Dengan demikian dapat ditarik satu definisi tentang SPK yaitu sebuah sistem berbasis komputer yang adaptif, fleksibel, dan interaktif yang digunakan untuk memecahkan masalah-masalah tidak terstruktur sehingga meningkatkan nilai keputusan yang diambil. (Khoirudin, 2008).

\section{Fuzzy Multi-Attribut Decision Making (FMADM)}

Fuzzy Multiple Attribute Decision Making adalah suatu metode yang digunakan untuk mencari alternatif optimal dari sejumlah alternatif dengan kriteria tertentu. Inti dari FMADM adalah menentukan nilai bobot untuk setiap atribut, kemudian dilanjutkan dengan proses perankingan yang akan menyeleksi alternative yang sudah diberikan. Pada dasarnya, ada 3 pendekatan untuk mencari nilai bobot atribut, yaitu pendekatan subyektif, pendekatan obyektif dan pendekatan integrasi antara subyektif \& obyektif. Masing-masing pendekatan memiliki kelebihan dan kelemahan. Pada pendekatan subyektif, nilai bobot ditentukan berdasarkan subyektifitas dari par pengambil keputusan, sehingga beberapa faktor dalam proses perankingan alternatif bisa ditentukan secara bebas. Sedangkan pada pendekatan obyektif, nilai bobot dihitung secara matematis sehingga mengabaikan subyektifitas dari pengambil keputusan (Kusumadewi, 2007). Ada beberapa metode yang dapat digunakan untuk menyelesaikan masalah FMADM antara lain (Kusumadewi, 2006):

- Simple Additive Weighting Method (SAW)

- Weighted Product (WP)

- ELECTRE

- Technique for Order Preference by Similarity to Ideal Solution (TOPSIS) 
- Analytic Hierarchy Process (AHP)

\section{Simple Additive Weighting Metod (SAW)}

Metode SAW sering juga dikenal istilah metode penjumlahan terbobot. Konsep dasar metod SAW adalah mencari penjumlahan terbobot dari rating kinerja pada setiap alternatif pada semua atribut. Metode SAW membutuhkan proses normalisasi matriks keputusan $(\mathrm{X})$ ke suatu skala yang dapat diperbandingkan dengan semua rating alternatife yang ada.

$r_{i j}=\left\{\begin{array}{lc}\frac{x_{i j}}{\max x_{i j}} & \text { jika j adalah atribut keuntungan (benefit) } \\ \frac{\min x_{i j}}{x_{i j}} & \text { Jika j adalah atribut biaya atau cost }\end{array}\right.$

Dimana rij adalah rating kinerja ternormalisasi dari alternatif Ai pada atribut Cj;i=1,2,..,m dan $\mathrm{j}=1,2, \ldots, \mathrm{n}$. Nilai preferensi untuk setiap alternatif ( Vi ) diberikan sebagai: $v_{i}=\sum_{j=1}^{n} w_{j} r_{i j}$

nilai $v_{i}$ yang lebih besar, mengindikasikan bahwa alternatif $A_{i}$ lebih terpilih.

\section{Langkah Penyelesaian}

Dalam penelitian ini menggunakan model FMADM metode SAW. Adapun langkah-langkahnya adalah:

1. Menentukan kriteria-kriteria yang akan dijadikan acuan dalam pengambilan keputusan, yaitu Ci.

2. Menentukan rating kecocokan setiap alternatif pada setiap kriteria.

3. Membuat matriks keputusan berdasarkan kriteria (Ci), kemudian melakukan normalisasi matriks berdasarkan persamaan yang disesuaikan dengan jenis atribut (atribut keuntungan ataupun atribut biaya) sehingga diperoleh matriks ternormalisasi R.

4. Hasil akhir diperoleh dari proses perankingan yaitu penjumlahan dari perkalian matriks ternormalisasi $\mathrm{R}$ dengan vector bobot sehingga diperoleh nilai terbesar yang dipilih sebagai alternatif terbaik (Ai) sebagai solusi (Kusumadewi, 2006). 


\section{Analisis}

\section{Tinjauan Umum}

Kebutuhan informasi merupakan kebutuhan yang ada pada sistem dan informasi yang dihasilkan oleh sistem. Kebutuhan informasi pada sistem pendukung keputusan untuk beasiswa yang diusulkan adalah:

\section{Kriteria yang dibutuhkan}

Berikut merupakan kriteria yang dibutuhkan untuk pengambilan keputusan berdasarkan persyaratan beasiswa secara umum. Adapun kriteria yang telah ditentukan yaitu Nilai IPK (C1), Penghasilan orang tua (C2), Semester (C3), Jumlah tanggungan orang tua (C4), dan Usia (C5).

Dari kriteria tersebut, maka dibuat suatu tingkat kepentingan kriteria berdasarkan nialai bobot yang telah ditentukan kedalam bilangan fuzzy. Rating kecocokan setiap alternatife pada setiap kriteria sebagai berikut:

Sangat Rendah $(\mathrm{SR})=0$

Rendah $(\mathrm{R})=2,5$

Cukup $(\mathrm{C})=5$

Tinggi $(\mathrm{T})=7,5$

Sangat Tinggi $(\mathrm{ST})=10$

Nilai bobot tersebut dibuat dalam sebuah grafik supaya lebih jelas, seperti dibawah ini.

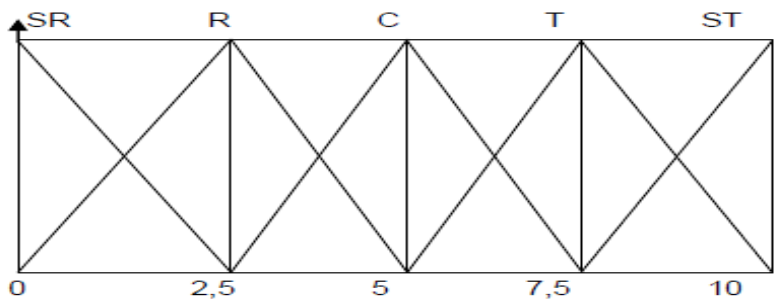

Gambar grafik bobot

Keterangan : 
$\mathrm{SR}=$ Sangat Rendah $\quad \mathrm{T}=$ Tinggi

$\mathrm{R}=$ Rendah $\quad \mathrm{ST}=$ Sangat Tinggi

$\mathrm{C}=$ Cukup Tinggi

Berdasarkan kriteria dan rating kecocokan setiap alternatif pada setiap kriteria yang telah ditentukan, selanjutnya penjabaran bobot setiap kriteria yang telah dikonversikan dengan bilangan fuzzy.

\section{- Kriteria nilai IPK}

Kriteria IPK merupakan persyaratan yang dibutuhkan untuk pengambilan keputusan, berdasarkan jumlah nilai IPK yang diperoleh oleh mahasiswa selama studi berlangsung. Berikut interval nilai IPK yang telah dikonversikan dengan bilangan fuzzy dibawah ini.

Tabel 3.1 Nilai IPK

\begin{tabular}{|l|l|}
\hline NILAI IPK & NILAI \\
\hline IPK $>3.00-<=3.25$ & 2.5 \\
\hline IPK $>3.25-<=3.5$ & 5 \\
\hline IPK $>3.5-<=3.75$ & 7.5 \\
\hline IPK $>3.75$ & 10 \\
\hline
\end{tabular}

\section{- Kriteria Penghasilan Orang tua}

Kriteria penghasilan orangtua merupakan persyaratan yang dibutuhkan untuk pengambilan keputusan, berdasarkan jumlah penghasilan tetap maupun tidak setiap bulannya. Berikut penjabaran interval jumlah penghasilan orangtua yang telah dikonversikan dengan bilangan fuzzy dibawah ini.

Tabel 3.2 Penghasilan orang tua

\begin{tabular}{|l|l|}
\hline Penghasilan Orang tua $(\mathrm{x})$ & Nilai \\
\hline $\mathrm{x}<=1.000 .000$ & 10 \\
\hline $\mathrm{x}>1.000 .000-<=2.000 .000$ & 7.5 \\
\hline $\mathrm{x}>2.000 .000-<3.000 .000$ & 5 \\
\hline $\mathrm{x}>=3.000 .000$ & 2.5 \\
\hline
\end{tabular}

\section{- Kriteria semester}


Kriteria semester merupakan persyaratan yang dibutuhkan untuk pengambilan keputusan, berdasarkan semester yang telah ditempuh. Berikut penjabaran interval semester yang telah dikonversikan dengan bilangan fuzzy dibawah ini.

Tabel 3.3 Semester

\begin{tabular}{|c|c|}
\hline Semester & Nilai \\
\hline 2 & 2 \\
\hline 3 & 4 \\
\hline 4 & 6 \\
\hline 5 & 8 \\
\hline 6 & 10 \\
\hline
\end{tabular}

\section{- Kriteria jumlah tanggungan orang tua}

Kriteria jumlah tanggungan orangtua merupakan persyaratan yang dibutuhkan untuk pengambilan keputusan, berdasarkan jumlah anak yang masih menjadi tanggungan orangtua berupa biaya hidup. Berikut penjabaran jumlah interval anak yang telah dikonversikan dengan bilangan fuzzy dibawah ini.

Tabel 3.4 Jumlah tanggungan orang tua

\begin{tabular}{|c|c|}
\hline $\begin{array}{l}\text { Jumlah tanggungan orang } \\
\text { tua }\end{array}$ & Nilai \\
\hline 1 anak & 0 \\
\hline 2 anak & 2.5 \\
\hline 3 anak & 5 \\
\hline 4 anak & 7.5 \\
\hline 5 anak & 10 \\
\hline
\end{tabular}

\section{- Kriteria Usia}

Kriteria usia merupakan persyaratan yang dibutuhkan untuk pengambilan keputusan, berdasarkan usia mahasiswa. Berikut penjabaran interval usia yang telah dikonversikan dengan bilangan fuzzy dibawah ini.

Tabel 3.5 Usia

\begin{tabular}{|l|l|}
\hline Usia & Nilai \\
\hline 18 tahun & 2 \\
\hline 19 tahun & 4 \\
\hline
\end{tabular}




\begin{tabular}{|l|l|}
\hline 20 tahun & 6 \\
\hline 21 tahun & 8 \\
\hline 22 tahun & 10 \\
\hline
\end{tabular}

\section{- Kriteria mengikuti organisasi kemahasiswaan}

Kriteria mengikuti organisasi kemahasiswaan merupakan syarat yang dibutuhkan untuk pengambilan keputusan, berdasarkan mengikuti atau tidaknya serta menjadi pengurus atau sebagai anggota dalam suatu organisasi kemahasiswaan. Berikut penjabaran interval yang telah dikonversikan dengan bilangan fuzzy dibawah ini:

Tabel 3.6 mengikuti organisasi kemahasiswaan

\begin{tabular}{|l|l|}
\hline $\begin{array}{l}\text { Mengikuti organisasi } \\
\text { kemahasiswaan }\end{array}$ & Nilai \\
\hline Pengurus organisasi & 10 \\
\hline Anggota aktif & 7.5 \\
\hline Anggota tidak aktif & 5 \\
\hline Tidak mengikuti organisasi & 2.5 \\
\hline
\end{tabular}

\section{Implementasi}

\section{Data pemohon}

Lima calon pemohon beasiswa memiliki data sebagai berikut:

Tabel 4.1 Data Pemohon

\begin{tabular}{|c|c|c|c|c|c|}
\hline \multirow[t]{2}{*}{ Kriteria } & \multicolumn{5}{|c|}{ Nama Pemohon } \\
\hline & $\begin{array}{l}\text { Mahasiswa } \\
1\end{array}$ & $\begin{array}{l}\text { Mahasiswa } \\
2\end{array}$ & $\begin{array}{l}\text { Mahasiswa } \\
3\end{array}$ & $\begin{array}{l}\text { Mahasiswa } \\
4\end{array}$ & $\begin{array}{l}\text { Mahasiswa } \\
5\end{array}$ \\
\hline Nilai IPK & 3.5 & 3.9 & 3.7 & 3.2 & 3.3 \\
\hline $\begin{array}{l}\text { Penghasilan } \\
\text { orang tua }\end{array}$ & 750.000 & 2.500 .000 & 1.000 .000 & 500.000 & 1.900 .00 \\
\hline Semester & 6 & 4 & 4 & 2 & 6 \\
\hline $\begin{array}{l}\text { Tanggungan } \\
\text { orang tua }\end{array}$ & 3 & 3 & 5 & 4 & 2 \\
\hline
\end{tabular}




\begin{tabular}{|l|l|l|l|l|l|}
\hline usia & 21 & 19 & 19 & 18 & 21 \\
\hline $\begin{array}{l}\text { Mengikuti } \\
\text { organisasi } \\
\text { kemahasiswaan }\end{array}$ & Pengurus & $\begin{array}{l}\text { anggota } \\
\text { aktif }\end{array}$ & $\begin{array}{l}\text { anggota } \\
\text { tidak aktif }\end{array}$ & $\begin{array}{l}\text { anggota } \\
\text { tidak aktif }\end{array}$ & pengurus \\
\hline
\end{tabular}

Berdasarkan data pemohon diatas dapat dibentuk matriks keputusan X yang telah dikonversikan dengan bilangan fuzzy, sebagai berikut :

Tabel 4.2 Rating kecocokan dari setiap alternatif pada setiap kriteria.

\begin{tabular}{|l|l|l|l|l|l|l|}
\hline Alternatif & C1 & C2 & C3 & C4 & C5 & C6 \\
\hline A1 & 5 & 10 & 10 & 5 & 8 & 10 \\
\hline A2 & 10 & 5 & 6 & 5 & 4 & 7.5 \\
\hline A3 & 7.5 & 10 & 6 & 10 & 4 & 5 \\
\hline A4 & 2.5 & 10 & 2 & 7.5 & 2 & 5 \\
\hline A5 & 5 & 10 & 10 & 2.5 & 2 & 10 \\
\hline
\end{tabular}

Pengambil keputusan memberikan bobot, berdasarkan tingkat kepentingan masing-masing kriteria yang dibutuhkan sebagai berikut :

Vektor bobot $\mathrm{W}=[10,7.5,5,2.5,2.5,2.5]$

Membuat matriks keputusan X, dibuat dari tabel kecocokan sebagai berikut:

$$
x=\left(\begin{array}{cccccc}
5 & 10 & 10 & 5 & 8 & 10 \\
10 & 5 & 6 & 5 & 4 & 7.5 \\
7.5 & 10 & 6 & 10 & 4 & 5 \\
2.5 & 10 & 2 & 7.5 & 2 & 5 \\
5 & 7.5 & 10 & 2.5 & 2 & 10
\end{array}\right)
$$

Pertama, dilakukan normalisasis matriks x untuk menghitung nilai masingmasing kriteria berdasarkan kriteria diasumsikan sebagai kriteria keuntungan atau biaya sebagai berikut:

$$
x=\left(\begin{array}{cccccc}
0.5 & 0.5 & 1 & 0.5 & 1 & 0.5 \\
1 & 1 & 0.6 & 0.5 & 0.5 & 0.67 \\
0.75 & 1 & 0.6 & 0.25 & 0.5 & 1 \\
0.25 & 0.5 & 0.2 & 0.33 & 0.25 & 1 \\
0.5 & 0.67 & 1 & 1 & 0.25 & 0.5
\end{array}\right)
$$


Selanjutnya akan dibuat perkalian matriks $\mathrm{W}^{*} \mathrm{x}$ dan penjumlahan hasil perkalian untuk memperoleh alternatife terbaik dengan melakukan perangkingan nilai terbesar sebagai berikut :

$$
\begin{aligned}
\mathrm{V} 1 & =(10)(0.5)+(7.5)(0.5)+(5)(1)+(2.5)(0.5)+(2.5)(1)+(2.5)(0.25) \\
& =5+3.75+5+1.25+2.5+1.25 \\
& =18.75 \\
\mathrm{~V} 2 & =(10)(1)+(7.5)(1)+(5)(0.6)+(2.5)(0.5)+(2.5)(0.5)+(0.25)(0.67) \\
& =10+7.5+3+1.25+1.25+1.675 \\
& =24.675 \\
\mathrm{~V} 3 & =(10)(0.75)+(7.5)(1)+(5)(0.6)+(2.5)(0.25)+(2.5)(0.5)+(2.5)(1) \\
& =7.5+7.5+3+0.625+1.25+2.5 \\
& =22.375 \\
\mathrm{~V} 4 & =(10)(0.25)+(7.5)(0.5)+(5)(0.2)+(2.5)(0.33)+(2.5)(0.25)+(2.5)(1) \\
& =2.5+3.75+1+0.825+0.625+2.5 \\
& =11.2 \\
\mathrm{~V} 5 & =(10)(0.5)+(7.5)(0.67)+(5)(1)+(2.5)(1)+(2.5)(0.25)+(2.5)(0.5) \\
& =5+5.025+5+2.5+0.625+0.125 \\
& =18.275
\end{aligned}
$$

Hasil perangkingan diperoleh:

Tabel 4.1 Hasil Perankingan

\begin{tabular}{|l|l|l|}
\hline alternative & $\mathrm{V}=\mathrm{W}^{*} \mathrm{x}$ & Ranking \\
\hline A1 & 18.75 & 3 \\
\hline A2 & 24.675 & 1 \\
\hline A3 & 22.375 & 2 \\
\hline A4 & 11.2 & 5 \\
\hline A5 & 18.275 & 4 \\
\hline
\end{tabular}

Nilai terbesar ada pada v2, dengan demikian alternatif A2 (mahasiswa 2) adalah alternatif yang terpilih.

\section{Kesimpulan}

Pembuatan Sistem Pendukung Keputusan untuk melakukan perhitungan sebagai penyeleksi data pemohon dengan hasil perengkingan mengacu pada rumusan masalah yang ada yaitu sistem dapat menyeleksi data pemohon sesuai ketentuan dengan melakukan perhitungan berdasarkan metode SAW (Simple 
Additive Weighting) pada FMADM (Fuzzy Multiple Attribute Decission Making). Hasil dari perhitungan sistem merupakan perangkingan nilai tertinggi ke rendah dan nilai tertinggi merupakan hasil yang dibutuhkan sebagai bahan pertimbangan oleh pembuat keputusan untuk memperoleh beasiswa.

\section{DAFTAR PUSTAKA}

[1] Kusrini. 2007. Strategi Perancangan dan Pengelohan Basis Data. Yogyakarta: Andi. Kusumadewi,Sri dkk. 2006. Fuzzy Multi-Attribute Decision Making (Fuzzy MADM). Yogyakarta: Graha Ilmu.

[2] Kusumadewi. 2005. Pencarian bobot atribut pada Multi-Attribute Decision Making dengan pendekatan objektif menggunakan algoritma genetika.

[3] http://cicie.files. wordpress. com/2008/06/sri-kusumadewi-jurnalgenetika.pdf. diakses 12 Januari 2012

[4] Turban dkk. 2005. Decision Support System and Intelligent System (Sistem Pendukung Keputusan dan Sistem Cerdas). Yogyakarta: Andi. 